\title{
Use of by-products of millet, amaranth and sorghum grains in bakery production
}

\author{
A.V. Volkova ${ }^{1 *}, A . V$. Kazarina $^{2}, O . N$. Antimonova $^{2}, Y u . Y u$. Nikonorova ${ }^{1}$, and $E . A$. Atakova ${ }^{2}$ \\ ${ }^{1}$ Samara State Agrarian University, Kinel 446442, Samara region, Russia \\ ${ }^{2}$ P.N. Konstantinov Volga Research Institute of Selection and Seed Production, Kinel 446442, Samara region, Russia
}

\begin{abstract}
The use of additional gluten-free grain raw materials in the form of flour or secondary raw materials of cereal industry in the recipes of bakery products allows regulating the biotechnological processes of dough maturing and proofing, obtaining a finished product with new functional properties and high nutritional value. The purpose of the research is to justify experimentally the use of processed products of amaranth grain and sorghum for the production of bread of high quality and functionality. The methodological basis of the study is presented by a systematic analysis of the technology for the production of bakery products enriched with promising phyto-fortifiers. In accordance with the chosen methodology, the chemical composition is analyzed and the positive effect of the use of flour from millet grain, sorghum and amaranth seeds in the mixture with premium wheat flour on the quality of bread is experimentally justified. It was found that the introduction of these types of additional raw materials had a positive effect on the activation of baking yeast and the maturation of dough. In the production of bread from wheat flour of the highest grade, it is optimal to use these phyto-fortifiers in the amount of $3 \%$ by weight of the composite mixture.
\end{abstract}

\section{Introduction}

Nowadays, the organization of nutrition of the population on a scientific and hygienic basis is carried out in the following areas: improvement of quality, biological value and taste of food products, assortment improvement, introducing new effective ways of production taking into account the rational use of raw materials, development of combined functional foods.

Taking into account the historically developed high proportion of the grain group in the consumer basket of the population of the Russian Federation, the research in the field of the design of recipe compositions and technologies for new types of bakery products, including those enriched with physiologically functional ingredients, is of essential value.

According to the Federal State Statistics Service and the marketing company Tebiz grup the volume of the production of bakery products in the Russian Federation in 2015 - 2017 was at the level of about 6 million tons. According to the results of 2017 , the sales volume of production amounted to 715.14 billion rubles. The production capacities of Russian enterprises for the production of bakery products were estimated in 10.1 million tons.

Nowadays, the share of enriched bakery products of average-plus and premium price segments does not exceed $3-5 \%$ of the total domestic bakery market. The companies focused on the production of social types of bread, as a rule, distinguish enriched bakery products in a special series with the status of healthy food products. The producers whose product is designed for an audience with a purchasing power of "average" and "above average", this product is presented as an elite product with an original taste. Supermarket bakeries consider such bakery products as a peculiar visiting card of their outlet, an indicator of its prestige and variety assortment, and modern consumers want to have a choice.

The use of promising enrichment of vegetable origin contributes to the intensification of the technological process of making bread, improving the organoleptic and physico-chemical parameters of bakery products, increasing their nutritional value [1-6], reducing the intensity of firming processes during storage [7, 8].

The use of gluten-free raw materials in the production of bread is one of the modern lines of research in this area. The relevance of this area of research is due to the significantly increased incidence of celiac disease in recent years, especially among children. At the same time, the issue of the enrichment of bakery products with micronutrients, the sources of which may be non-cereal grain and seeds of other crops, is still relevant relevant.

As an additional gluten-free raw material, millet grain, sorghum and amaranth seeds can be used, which from ancient times were a part of human nutrition, but recently they have not attracted due attention. Many authors noted the possibility of using flour from the

\footnotetext{
* Corresponding author: avvolkova76@ rambler.ru
} 
grain of these crops in the production of bakery products as a part of composite mixtures [9-11], while emphasizing the texture properties and sensory acceptability of such composite bread [12, 13]. In addition, it is necessary to note that the result of selection achievements is to increase the physiological value of the grain of these crops $[14,15]$, which, in turn, will have a beneficial effect on the nutritional value of bakery products.

The purpose of this research is to experimentally justify the use of millet and sorghum amaranth grain products for the production of high quality and functional bread. The research tasks are as follows: 1) to determine the quality of bread from wheat flour of the highest grade using by-products of the grain of millet, amaranth and sorghum according to organoleptic and physico-chemical indicators; 2) to determine the optimal dosage of grain components in the production of bread from premium wheat flour; 3) to optimize the recipe components of bread using the by-products of the grain of millet, amaranth and sorghum. The object of the research is bakery products of high nutritional value using the by-products of grain of millet, amaranth and sorghum, their technologies and recipes. The subject of the study is the effect of these phyto-fortifiers on the quality and nutritional value of finished bakery products.

The development of recipes for bakery products using promising phyto-fortifiers is of great theoretical and practical interest and creates the prerequisites for the expansion of the range, quality improvement, increase of nutritional and biological value of the finished product.

\section{Material and methods}

In the experiments, a straight dough method for bread preparation was used. During the research, wheat flour of the highest grade was used. The bread production by the experimental variants was carried out using the test laboratory baking method with its subsequent assessment according to quality indicators of generally accepted methods.

Three types of flour were used as additional raw materials: millet flour, amaranth flour and sorghum flour, which were introduced into the recipe in the amount of $1,3,5,7$, and $10 \%$ by weight of the composite mixture.

All the experiments described in the work were performed in 3-4-fold repetition and analytical determinations for each sample were made in at least three replicates. The tables show data from typical experiments. Each value is the average of three or more definitions. Only those results that were reproducible in each experiment are discussed. The deviations in each case do not exceed $1-3 \%$.

\section{Research results}

Before laboratory tests, the autgors investigated the quality indicators of raw materials: premium-grade wheat flour and composite mixtures that characterize their suitability for baking. Premium baking wheat flour had a taste typical of this product, a white color with a cream tint, and a smell typical of wheat baking flour (Table 1). In the experiment, wheat flour of the highest grade was used.

Table 1. Organoleptic and physico-chemical indicators of the quality of wheat flour used in the research

\begin{tabular}{|c|c|c|}
\hline \multirow[t]{2}{*}{ Item } & \multicolumn{2}{|c|}{ Item value } \\
\hline & $\begin{array}{l}\text { State Standard } \\
\text { requirements } \\
52189-2003\end{array}$ & Actual value \\
\hline Taste & $\begin{array}{l}\text { Peculiar to wheat } \\
\text { flour, without } \\
\text { off-flavors, not } \\
\text { sour, not bitter }\end{array}$ & $\begin{array}{l}\text { Peculiar to wheat } \\
\text { flour, without off- } \\
\text { flavors, not sour, } \\
\text { not bitter }\end{array}$ \\
\hline Colour & $\begin{array}{l}\text { White or white } \\
\text { with a cream tint }\end{array}$ & Creamy white \\
\hline Smell & $\begin{array}{l}\text { Peculiar to wheat } \\
\text { flour, without } \\
\text { off-odors, not } \\
\text { fusty, not moldy }\end{array}$ & $\begin{array}{l}\text { Peculiar to wheat } \\
\text { flour, odor-free }\end{array}$ \\
\hline $\begin{array}{l}\text { Moisture } \\
\text { content, \% }\end{array}$ & $\begin{array}{c}\text { Not more than } \\
15.0\end{array}$ & 11.3 \\
\hline $\begin{array}{l}\text { Mineral } \\
\text { additive } \\
\text { content }\end{array}$ & $\begin{array}{l}\text { No crunch when } \\
\text { chewing flour }\end{array}$ & $\begin{array}{l}\text { No crunch when } \\
\text { chewing flour }\end{array}$ \\
\hline $\begin{array}{l}\text { Pest } \\
\text { contamination }\end{array}$ & Is not allowed & Not found \\
\hline Pest pollution & Is not allowed & Not found \\
\hline $\begin{array}{l}\text { Ash weight } \\
\text { content, \% }\end{array}$ & $\begin{array}{c}\text { Not more than } \\
0.55\end{array}$ & 0.50 \\
\hline $\begin{array}{l}\text { Crude gluten } \\
\text { weight } \\
\text { content, \% }\end{array}$ & $\begin{array}{c}\text { Not less than } \\
28.0\end{array}$ & 29.92 \\
\hline $\begin{array}{l}\text { Gluten } \\
\text { quality, un. } \\
\text { FDM }\end{array}$ & - & 82.0 \\
\hline $\begin{array}{l}\text { Gluten } \\
\text { quality group }\end{array}$ & Not lower than II & II \\
\hline $\begin{array}{l}\text { Falling- } \\
\text { number, s }\end{array}$ & Not less than 185 & 346 \\
\hline $\begin{array}{l}\text { Acid content, } \\
\text { degree }\end{array}$ & - & 2.2 \\
\hline
\end{tabular}

According to the organoleptic and physico-chemical quality indicators, premium grade wheat flour met the requirements of the standard. The analysis of the chemical composition of the grain of the studied crops by the content of substances that determine their biological and physiological value was conducted (table 2 ). The results of the research show that the flour from the grain of the studied crops is characterized by a high, comparable to the wheat flour, protein content, dispensable and indispensable amino acids.

Therefore, in the production of bakery products they can act as a substitute component in composite mixture. It is noted that the highest content of amino acids, in almost all of their types defined by the authors, is characteristic of flour from amaranth. Millet and sorghum flour is characterized by he thighest protein 
content. However, it is necessary to note that the flour from the grain of these crops has a rather high fat content, especially amaranth, which makes it more prone to rapid rancidity during storage.

Table 2. The content of nutrients and amino acids in flour from amaranth, millet and sorghum grains

\begin{tabular}{|l|c|c|c|}
\hline Components & $\begin{array}{c}\text { Amaranth } \\
\text { flour }\end{array}$ & $\begin{array}{c}\text { Millet } \\
\text { flour }\end{array}$ & $\begin{array}{c}\text { Sorghum } \\
\text { flour }\end{array}$ \\
\hline Water, \% & 9.83 & 9.43 & 9.79 \\
\hline Protein, \% & 9.65 & 11.05 & 10.43 \\
\hline Fat, \% & 6.93 & 3.44 & 3.61 \\
\hline Fiber, \% & 2.89 & 2.49 & 2.84 \\
\hline Ash, \% & 2.81 & 2.94 & 3.38 \\
\hline \multicolumn{4}{|c|}{ Dispensable amino acids, \% } \\
\hline arginine & 2.88 & 0.39 & 0.57 \\
\hline alanine & 0.74 & 0.79 & 0.66 \\
\hline histidine & 2.23 & 0.35 & 0.17 \\
\hline glycine & 2.05 & 0.25 & 0.22 \\
\hline proline & 1.84 & 0.56 & 0.66 \\
\hline serine & 1.34 & 0.59 & 0.29 \\
\hline \multicolumn{4}{|c|}{ Indispensable acids, \% } \\
\hline valine & 1.24 & 0.39 & 0.34 \\
\hline leucine + isoleucine & 2.24 & 1.35 & 1.54 \\
\hline lysine & 1.12 & 0.16 & 0.17 \\
\hline methionine & 0.43 & 0.39 & 0.12 \\
\hline threonine & 0.27 & 0.24 & 0.15 \\
\hline tyrosine & 0.42 & 0.13 & 0.23 \\
\hline phenylalanine & 0.70 & 0.71 & 0.39 \\
\hline \multicolumn{4}{|c|}{ Microelement content, mg/100g } \\
\hline Potassium (P) & 465.80 & 241.78 & 363.87 \\
\hline Calcium (Ca) & 146.50 & 273.55 & 220.56 \\
\hline Magnesium (Mg) & 263.90 & 148.60 & 165.87 \\
\hline Phosphorus (P) & 3.49 & 6.38 & 32.15 \\
\hline
\end{tabular}

The consequence of thepeculiarities of chemical composition of the grain was that the properties of the main raw material changed depending on the type of additional raw material and its share in the composite mixture (Table 3).

Flour from amaranth, millet and sorghum grains is a raw material with a high protein content and, at the same time, a gluten-free component. This feature is the reason for the changes in the physicochemical parameters of the quality of composite mixtures. Thus, with the increase in the weight content of the gluten-free in the composite mixtures, the weight content of water-soluble proteins in them increases. The consequence of this is a slight increase in the water absorption capacity of flour in the variants using amaranth and millet flour. It is interesting, that this trend is not observed in the variants with sorghum flour, which indicates the need for a more detailed approach when studying the characteristics of the chemical composition of the grain of this culture.

The introduction of a gluten-free component into the composite mixture, logically, led to a regular decrease in the weight content of crude gluten in it. In addition, significant features of changes in the quality of gluten are noted. When amaranth flour is introduced into the composite mixture, gluten loses its elastic properties by up to 20 units. FDM is more deformed. Sorghum flour grains in the composite mixture, on the contrary, contribute to its strengthening. On all variants of composite mixtures, the increase in the viscosity of the mixture and the number of drops compared to the variant accepted for control is noted.

During the study of the influence of additional types of raw materials on the activity of baking yeast and dough quality, it was noted that their use increases the rising force of yeast. The increase in the acid content of dough on these variants also indicates the activation of yeast when using millet, amaranth and sorghum flour (Table 4).

Table 3. Physico-chemical quality indicators of flour and composite mixtures

\begin{tabular}{|c|c|c|c|c|c|}
\hline $\begin{array}{l}\text { Additional raw } \\
\text { material variant }\end{array}$ & $\begin{array}{l}\text { Weight content of additional } \\
\text { raw materials in the composite } \\
\text { mixture, } \%\end{array}$ & $\begin{array}{c}\text { Water } \\
\text { absorbing } \\
\text { capacity,\% }\end{array}$ & $\begin{array}{l}\text { Weight content } \\
\text { of crude } \\
\text { gluten, } \%\end{array}$ & $\begin{array}{l}\text { Gluten quality, } \\
\text { un. FDM }\end{array}$ & $\begin{array}{l}\text { Falling- } \\
\text { number, s }\end{array}$ \\
\hline Control & - & 58.0 & 29.92 & 82.0 & 346.0 \\
\hline \multirow{5}{*}{$\begin{array}{l}\text { Amaranth } \\
\text { flour }\end{array}$} & 1 & 56.0 & 29.08 & 101.0 & 405.0 \\
\hline & 3 & 57.0 & 28.88 & 100.0 & 445.0 \\
\hline & 5 & 57.0 & 28.88 & 102.0 & 411.0 \\
\hline & 7 & 58.0 & 28.56 & 101.0 & 398.0 \\
\hline & 10 & 60.0 & 28.40 & 90.0 & 362.0 \\
\hline \multirow{5}{*}{$\begin{array}{l}\text { Millet } \\
\text { flour }\end{array}$} & 1 & 58.0 & 29.58 & 98.0 & 396.0 \\
\hline & 3 & 59.0 & 28.65 & 98.0 & 402.0 \\
\hline & 5 & 60.0 & 27.30 & 95.0 & 423.0 \\
\hline & 7 & 60.0 & 28.74 & 91.0 & 449.0 \\
\hline & 10 & 60.0 & 28.33 & 88.0 & 401.0 \\
\hline \multirow{5}{*}{$\begin{array}{l}\text { Sorghum } \\
\text { flour }\end{array}$} & 1 & 58.0 & 29.12 & 85.0 & 394.0 \\
\hline & 3 & 57.0 & 28.61 & 86.0 & 436.0 \\
\hline & 5 & 56.0 & 28.28 & 79.0 & 432.0 \\
\hline & 7 & 56.0 & 28.23 & 73.5 & 463.0 \\
\hline & 10 & 56.0 & 28.03 & 70.9 & 396.0 \\
\hline
\end{tabular}


Table 4. Change in the active acid content of dough depending on the type of flour and its share in the composite mixture

\begin{tabular}{|c|c|c|c|c|c|c|c|c|}
\hline \multirow{2}{*}{$\begin{array}{l}\text { Additional raw } \\
\text { material variant }\end{array}$} & \multirow{2}{*}{$\begin{array}{l}\text { Weight content of } \\
\text { additional raw } \\
\text { materials in the } \\
\text { composite mixture, } \%\end{array}$} & \multicolumn{7}{|c|}{ Dough time, min. } \\
\hline & & 0 & 30 & 60 & 90 & 120 & 150 & 170 \\
\hline Control & - & 2.4 & 2.8 & 2.9 & 3.0 & 3.0 & 3.0 & 3.0 \\
\hline \multirow{5}{*}{$\begin{array}{l}\text { Amaranth } \\
\text { flour }\end{array}$} & 1 & 2.4 & 2.9 & 3.0 & 3.1 & 3.1 & 3.1 & 3.1 \\
\hline & 3 & 2.6 & 3.0 & 3.4 & 3.6 & 3.7 & 3.7 & 3.7 \\
\hline & 5 & 2.8 & 3.2 & 3.2 & 3.7 & 3.7 & 3.7 & 3.7 \\
\hline & 7 & 3.2 & 3.5 & 3.7 & 3.9 & 4.0 & 4.0 & 4.0 \\
\hline & 10 & 3.6 & 3.9 & 4.1 & 4.2 & 4.2 & 4.2 & 4.2 \\
\hline \multirow{5}{*}{$\begin{array}{l}\text { Millet } \\
\text { flour }\end{array}$} & 1 & 2.3 & 2.8 & 3.0 & 3.0 & 3.0 & 3.1 & 3.1 \\
\hline & 3 & 2.4 & 2.9 & 2.9 & 3.0 & 3.1 & 3.1 & 3.1 \\
\hline & 5 & 2.5 & 3.0 & 3.1 & 3.2 & 3.2 & 3.2 & 3.2 \\
\hline & 7 & 2.6 & 3.0 & 3.2 & 3.3 & 3.3 & 3.3 & 3.3 \\
\hline & 10 & 2.6 & 3.0 & 3.2 & 3.3 & 3.3 & 3.3 & 3.3 \\
\hline \multirow{5}{*}{$\begin{array}{l}\text { Sorghum } \\
\text { flour }\end{array}$} & 1 & 2.4 & 2.6 & 2.7 & 3.0 & 3.1 & 3.1 & 3.0 \\
\hline & 3 & 2.5 & 2.6 & 2.7 & 3.0 & 3.1 & 3.0 & 3.0 \\
\hline & 5 & 2.5 & 2.6 & 2.8 & 3.2 & 3.3 & 3.2 & 3.3 \\
\hline & 7 & 2.6 & 2.7 & 2.8 & 3.4 & 3.5 & 3.4 & 3.4 \\
\hline & 10 & 2.7 & 2.8 & 2.8 & 3.4 & 3.5 & 3.4 & 3.4 \\
\hline
\end{tabular}

The table shows that the use of millet, amaranth and sorghum flour in the composite mixture contributed to the yeast activation. It is proved by more rapid accumulation of acids during fermentation of dough.

The increase in titratable acidity is associated with enzymatic hydrolysis of biopolymers and the accumulation of fermentation products. Yeast activation is more effective when using amaranth flour. This is a consequence of a higher content of dispensable and in dispensable amino acids in it, which stimulate the starting development of yeast culture. A similar pattern was manifested in the determination of the rising power of yeast in the dough ball. The dough ball rising time was reduced by $\begin{array}{llll}6.0 & \ldots & 12 & \text { minutes compared to the }\end{array}$ control variant. Minimum ascent time was also noted when using amaranth flour.

A similar pattern of changes in acid content depending on the weight content of additional raw materials in the composite mixture remained in the finished bread products (Table 5).

Table 5. Physico-chemical quality indicators of bread from wheat flour of the highest grade and composite mixtures

\begin{tabular}{|c|c|c|c|c|c|}
\hline $\begin{array}{l}\text { Additional raw } \\
\text { material variant }\end{array}$ & $\begin{array}{c}\text { Weight content of } \\
\text { additional raw materials } \\
\text { in the composite } \\
\text { mixture, } \%\end{array}$ & $\begin{array}{l}\text { Average bakery } \\
\text { grade, points }\end{array}$ & $\begin{array}{c}\text { Crumb } \\
\text { porosity, } \%\end{array}$ & $\begin{array}{c}\text { Crumb } \\
\text { moisture, \% }\end{array}$ & $\begin{array}{c}\text { Crumb acid } \\
\text { content, degree }\end{array}$ \\
\hline Control & - & 4.86 & 76.54 & 33.82 & 1.80 \\
\hline \multirow{5}{*}{$\begin{array}{l}\text { Amaranth } \\
\text { flour }\end{array}$} & 1 & 4.72 & 79.46 & 37.21 & 2.10 \\
\hline & 3 & 4.86 & 79.38 & 37.85 & 2.10 \\
\hline & 5 & 4.86 & 80.61 & 37.87 & 2.30 \\
\hline & 7 & 4.72 & 80.33 & 37.40 & 2.40 \\
\hline & 10 & 4.45 & 82.52 & 39.87 & 2.70 \\
\hline \multirow{5}{*}{$\begin{array}{l}\text { Millet } \\
\text { flour }\end{array}$} & 1 & 4.72 & 80.60 & 35.29 & 2.10 \\
\hline & 3 & 4.82 & 80.52 & 38.80 & 2.10 \\
\hline & 5 & 4.72 & 80.86 & 37.22 & 2.10 \\
\hline & 7 & 4.72 & 81.31 & 37.03 & 2.30 \\
\hline & 10 & 4.57 & 80.66 & 36.41 & 2.30 \\
\hline \multirow{5}{*}{$\begin{array}{l}\text { Sorghum } \\
\text { flour }\end{array}$} & 1 & 4.86 & 77.88 & 37.84 & 2.10 \\
\hline & 3 & 4.86 & 80.00 & 37.44 & 2.10 \\
\hline & 5 & 4.72 & 78.53 & 37.05 & 2.10 \\
\hline & 7 & 4.72 & 78.45 & 37.86 & 2.20 \\
\hline & 10 & 4.72 & 78.24 & 36.88 & 2.30 \\
\hline
\end{tabular}


The results of a test laboratory baking showed that the bread produced using additives based on amaranth, sorghum and millet grain in an amount of not more than $3 \%$ by weight of the composite mixture was characterized by the best appearance.

The samples of bread on these variants were with more even and convex crust. The crust color was brown with a more pronounced rosy tint.

The color of the crumb remained white with a yellowish tint, the crumb was soft, elastic, with fairly uniform porosity after pressing, it easily restored the structure. The crumb porosity when using additives based on millet grain was finer, thin-walled and more even.

\section{Discussion}

In recent decades, the attention of researchers from various fields of knowledge is increasingly attracted by the problem of the appearance of new physiological disorders and human diseases, such as celiac disease. Scientists associate their appearance with poor nutrition, environmental degradation, stress factors, and urbanization processes. Treatment is often accompanied by the following certain diets, which include the introduction of foods with a low protein content as a whole or its individual fractions.

The main source of gluten - the protein fraction that causes the development of celiac disease is an indispensable food product that is included in the diet of almost every person - bread, taking into account that at present the trend of a "healthy" lifestyle and a healthy diet opens up broad prospects for the development of the range of bakery products with the use of additional gluten-free raw materials.

The research results show that grain and flour of such crops as millet, amaranth and sorghum, being glutenfree, are nevertheless characterized by a rather high content of protein, dispensable and indispensable amino acids.

The analysis of the chemical composition indicates that the amino acid composition in terms of variety and weight content of the individual components is not inferior, but in some positions, it exceeds the corresponding values characteristic of premium wheat flour. This allows concluding that the flour obtained from the grain of these crops is physiologically more valuable and can be used as a substitute component in the composite mixture with premium wheat flour.

In addition to the increase of the physiological value of the finished product, the use of flour from millet, sorghum and amaranth has a positive effect on the ripening of dough, which is explained by its high content of mono-, disaccharides, dispensable and indispensable amino acids and minerals.

Taking into account that many bakeries of average, and especially low power, often use a straight dough method to reduce the duration of the production cycle, this aspect is of particular importance since, with a significantly reduced duration of the fermentation process, the dough does not accumulate a sufficient amount of substances that cause the flavour of bread and the intensity of its stalling. The activation of baker yeast with the use of the considered types of additional raw materials, especially flour from amaranth seeds, will partially solve this problem.

In this way the problem can be solved partially because the organoleptic and physico-chemical parameters of the finished bread are the limiting factor in the design of recipe compositions and technologies for new types of bakery products, including those enriched with physiologically functional ingredients.

The optimal values of these indicators are achieved at fairly low values of the weight content of additional raw materials in the composite mixtures. Thus in the presented experiments, the best values of consumer properties were characterized by bread produced with the use of amaranth, sorghum and millet flour in an amount of not more than $3 \%$ by weight of the composite mixture.

The hardware-technological scheme for the production of bread using amaranth, sorghum and millet flour does not require changes, and therefore new types of products can be produced at any bakery.

\section{Conclusion}

The use of additional gluten-free grain raw materials in the production of bread is an urgent and promising direction in both scientific and industrial activities, as the emphasis on the health aspect is currently one of the most powerful factors in the liquidity of bakery products.

The use of flour from millet, sorghum and amaranth grain has a positive effect on the maturation of the dough, which is explained by its high content of mono-, disaccharides, dispensavle and indispensable amino acids and minerals.

The best values of consumer properties were characterized by bread produced with the use of amaranth, sorghum and millet flour in the amount of not more than $3 \%$ by weight of the composite mixture.

\section{References}

1. K. P. Singh, A. Mishra, H. N. Mishra, LWT - Food Science and Technology 48, 276-282 (2012)

2. C. M. Rosell, R. Garzon, Food Microstructure and Its Relationship with Quality and Stability 217-238 (2018)

3. Enkhjargal Ulziijargal, Joan-Hwa Yang, Li-Yun Lin, Chiao-Pei Chen, Jeng-Leun Mau, Food Chemistry 138, 70-76 (2013)

4. Z. H. Al-Attabi, T. M. Merghani, A. Ali, M. S. Rahman, J. of Cereal Science 75, 61-68 (2017)

5. Y. Wang, D. Compaoré-Sérémé, H. SawadogoLingani, R. Coda, N. H. Maina, Food Chemistry 285, 221-230 (2019) 
6. A. Torbica, M. Belović, J. Tomić, Food Chemistry 282, 134-140 (2019)

7. E. Debonne, I. De Leyn, J. Verwaeren, S. Moens, F. Van Bockstaele, LWT 93, 212-219 (2018)

8. E. Debonne, F. Van Bockstaele, I. De Leyn, F. Devlieghere, M. Eeckhout, LWT 87, 368-378 (2018)

9. A.P. Barba de la Rosa, B. Laursen, A. G. Mortensen, L. Olvera-Martínez, C. Silva-Sánchez, A. MendozaHerrera, J. González-Castañeda, A. De LeónRodríguez, J. of Cereal Science 49, 117-121 (2009) DOI 10.1016/j.jcs.2008.07.012

10. M. A. Kurek, S. Karp, J. Wyrwisz, Y. Niu, Food Hydrocolloids 85, 321-330 (2018) DOI 10.1016/j.foodhyd.2018.07.021
11. A. Torbica, M. Belović, J. Tomić, Food Chemistry 282, 134-140 (2019) DOI 10.1016/j.foodchem.2018.12.113

12. Sh. S. Patil, Sh. G. Rudra, E. Varghese, C. Kaur, Food Bioscience 14, 62-69 (2016) DOI 10.1016/j.fbio.2016.04.001

13. R. Schoenlechne, M. Szatmari, A. Bagdi, S. Tömösközi, LWT - Food Science and Technology 51, 361-366 (2013) DOI 10.1016/j.lwt.2012.10.020

14. M.T. Labuschagne, J. of Cereal Science 84, 151-158 (2018) DOI 10.1016/j.jcs.2018.10.010

15. G. Liu, E. K. Gilding, E. D. Kerr, B. L. Schulz, B. Tabet, B. R. Hamaker, J. of Cereal Science 85, $27-$ 34 (2019) DOI 10.1016/j.jcs.2018.11.001 